\title{
Have Credit Rating Agencies Got a Role in Triggering 2007 Global Financial Crisis?
}

\author{
Prof. Dr. Ersan Bocutoğlu (Karadeniz Technical University, Turkey)
}

\begin{abstract}
The efforts for understanding the 2007 Global Financial Crisis requires more elaborated studies on the institutions, processes and other micro foundations of financial services industry instead of studies solely on mainstream business cycles theories that have obviously failed in understanding, explaining and predicting the crisis. This paper attempts to investigate whether or not credit rating agencies had played a triggering role in 2007 Global Financial Crisis. It is a study of parties, institutions and processes within financial services market. It is well documented that the credit rating agencies whose main function is to provide investors with information about the credit-worthiness of securities on which they plan to invest had hardly ever performed that function properly during the crisis. By changing their business models from 'investor pays model' to 'issuer pays model', they paved the way to conflict of interest and inevitably created chaos in financial services industry. Credit rating agencies doubtlessly are responsible for triggering the 2007 Global Financial Crisis. However it should be fair to emphasize also the responsibility of the US regulatory processes in emerging the conflict of interest in credit rating industry by giving some credit rating agencies an oligopoly power in the credit rating market and taking their credit ratings as the basic points of reference for regulatory purposes. It is obvious that the credit rating industry needs a reform.
\end{abstract}

\section{Introduction}

Among other factors, the role credit rating agencies (CRAs) played in 2007 Global Financial Crisis has been extensively investigated (Bocutoğlu, 2014). The attention has been attracted recently to CRAs by the fact that the US Security and Exchange Commission (SEC) suspended the activities of Standard and Poor's (SફP) in the Commercial Mortgage Based Securities market for one year during January 21, 2015- January 21, 2016 because of that it caused loses to the investors by slackening secretly the assumptions of its credit rating model it announced publicly and therefore supplying fake - inflated - credit scores (Whitehouse, 2015).

While CRAs are criticized because of lack of competition, lack of accountability, lack of independence, lack of timeliness and pro-cyclical behavior, and rating triggers (McVea, 2010, Ryan, 2012), the main attack to them is for that their credit rating process proceeds under heavy conflict of interest. According to critics CRAs produce credit ratings with low quality of information about credibility of asset backed mortgages that are of extremely complex structures, their sudden downgrades of credit ratings do not contribute to the stability of the market but produce chaos and they are in lack of unaccountability in financial services industry despite the market power they have (McVea, 2010).

From the end of 2007 summer onwards CRAs had downgraded tremendously the credit ratings of assets backed mortgages and carried on this practice up to 2008 fall. On September 15, 2008 the big three consisting of S§P, Moody's and the Fitch downgraded the credit ratings of AIG, the biggest insurance company in the US due to the loss of stock value of AIG at the rate of $61 \%$. On the very day, Lehman Brothers and Merill Lynch went bankrupt. A while ego Bear Stern declared that it became insolvent and could not fulfill its obligations. After a couple of days Chairman of the Fed Bernanke and Treasury Secretary Paulson asked the Congress whether or not the Congress could buy subprime bed debt of 700 billion dollars. President Bush warned that the American economy as a whole would be in danger of collapse without immediate bail out support of the Congress.

Although CRAs' downgrading the credit ratings is not solely a cause of the crisis, it reveals that CRAs have produced inflated credit ratings. When taking into account of the given incentive system it is not surprising to see that issuers, investors, CRAs and regulators made fatal mistakes. The regulations in 1936 and 1973 implemented by the US Office of the Comptroller of the Currency (OCC) and the SEC respectively depended upon the credit ratings produced by the CRAs. Due to these regulations, a very limited number of CRAs were allowed to take part in credit rating market, the credit rating models and methodologies that CRAs adopted were accepted sufficient and therefore large-scale potential risks were born in financial services industry.

The malfunctioning of CRAs increased the need for international cooperation on a reform in credit rating industry. Financial Stability Commission that was set up in 2009 by D-20 to provide financial stability issued a report calling governments for reducing dependency on CRAs (Ryan, 2012).

This paper attempts to investigate whether or not CRAs had played a triggering role in 2007 Global Financial Crisis. It is a study of parties, institutions and processes within financial services market. 


\section{Credit Rating Agencies}

\subsection{Definition and the Scope of Credit Rating Agencies}

Credit rating agencies can be simply defined as institutions that are specialized in supplying information on credibility of securities or bonds issued by firms, municipalities and states. The credibility is possibility whether or not principal and interest of a certain security or bond are paid when due. Credit ratings can be executed both on debts of the issuers, namely general financial health of the issuers and on the assets that form a financial package as is the case of structured asset-backed securities (Ekins and Calabria, 2012). Credit rating agencies produce ratings by using certain letters and the letters symbolize the opinion of CRAs about credibility of securities or bonds at a certain date. It is important to state that these opinions are subjective and not necessarily represent the accurate forecasts. CRAs' functions can be grouped under three general headings: (i) providing information and assessment for investors, (ii) enabling issuers to access capital markets, (iii) helping regulators to regulate (Ryan, 2012).

It is estimated that there are about 130 CRAs across the world differed in scales, scope of interests and methodologies they use. Among them Standard and Poor's, Moody's and the Fitch are the biggest and they effectively operate globally mainly in financial services industries of the US and the United Kingdom (McVea 2010).

Changes in credit ratings are at stake when there is possibility of large-scale delinquencies but not small-scale credit risk changes in the short run. The rating method of a CRA is 'evaluation in conjuncture' and not 'evaluation at a point'. This means that CRAs do not continuously renew the information about the securities once they rated. They assume that the evaluations they made remain relatively stable in time (Ekins and Calabria, 2012). As a matter of fact the parties that intent to hold securities for longer period of time are not interested in short-term volatility of risk in the financial markets. Frequent changes in credit ratings of a financial instrument make the instrument more costly in that they increase the volatility and assurance of the instrument, and call for quick repayment. The performance of credit ratings represents the reputation of a CRA that performs the ratings and it is expected that changes in the reputation have substantial effects on general performance and profitability of the CRAs.

\subsection{How is the Credit Rating Services Financed?}

There are two business models to price the credit rating services: 'investors pay model' and 'issuers pay model'. In investors pay model, CRAs evaluate the financial instruments and sell the credit ratings to their investor subscribers. The main clients in this model are investors. CRAs have to produce correct information for their clients about the creditworthiness of securities under rating so as to be able to keep them in subscription list and to make money. In issuers pay model, CRAs evaluate the financial instruments upon issuers' request and sell the credit ratings to the issuers. The main clients in this model are issuers. Then the issuers use the credit ratings as some kind of certification that shows the quality and soundness of the financial product they have issued, and sell them to the investors. It is clear that this certification gives confidence to the investors. In the second model, the issuers benefit substantially from the higher credit ratings given by the CRAs. On the other hand, investors take into account the reputation of the CRA that has made the rating and the probability that the credit rating reflects the correct information about the financial instruments.

The issuers typically buy two credit ratings produced by different CRAs for each instrument they have issued. If the difference between two credit ratings are great than the issuers try a third rating. On the contrary, the investors generally rely on one credit rating. If investor is a commercial bank and its same security has different credit ratings, principally the lower rating is depended on calculating the risk that the security may have. In the decision of keeping a certain security at hand, only one credit rating is relied. If a certain security has more than one credit rating, the higher rate is considered (Ekins and Calabria, 2012, Hunt, without date).

\subsection{Brief History of Credit Rating Agencies}

Although the first credit reporting firm The Mercantile Agency was set up in 1841 for eliminating the asymmetric information that had given way to 1837 financial crisis, modern credit rating industry is the artifact of John Moody and Henry Poor who had collected information on railway bonds market and conveyed them to their subscribers by $20^{\text {th }}$ century. Moody's Analyses Publishing Company in 1909, H.V. And H.V. Poor Company in 1906, Standard Statistic Company in 1922 and Fitch Publishing Company in 1924 appeared. As the newcomers were increasing in the industry, an information infrastructure necessary for bonds market was developed.

The firms John Moody's and Henry Poor's were recognized across the financial services industry with their correct forecasts during 1929 Great Depression and this made them gain higher reputation in the market. As the 1945-1970 period was fairly stable, the demand for credit ratings started to increase through 1970s.

There are basically three reasons why CRAs have grown in importance in due course. First of all since Regulation Q of 1933 Glass-Steagall Act banned commercial banks to pay interest for checking accounts, the deposits of commercial banks had almost dried out and therefore their loans capacity was severely restricted 
(Ekins and Calabria, 2012). Together with this new state of affairs, demand for loans had tended to turn from commercial banking to non-commercial credit institutions. Since non-commercial credit institutions did not have credit rating infrastructure that commercial banks had, they turned their faces to the big CRAs. As a matter of course the demand for credit ratings increased. Secondly the fact that the firms departed away from commercial banks due to the higher inflations during the 1975-1980 period fostered the non-financial commercial paper market to grow by $\% 300$. By the same token higher demand for structured financial instruments such as commercial mortgage-backed securities increased the demand for credit ratings. The fact that the SEC and Basel II framework referenced credit ratings as a benchmark in regulations and banks' capital requirements respectively increased the importance of the credit rating agencies. Finally globalization also increased the demand for credit ratings since the new financial products require credit ratings.

\section{Oligopoly in Credit Rating Industry}

In the USA financial services industry and credit rating industry have been working in closely interrelated manner since 1975. The SEC allowed solely credit rating agencies with Nationally Recognized Statistical Rating Organizations designation to operate in credit rating industry. The restrictions imposed by the SEC on credit rating agencies to enter the industry have created an oligopoly in credit rating market dominated by the big tree, consisting of Standard and Poor's, Moody's and Fitch (Ekins and Calabria, 2012). The fact that the SEC and Basel II framework referenced credit ratings as a benchmark in regulations and banks' capital requirements respectively increased the importance of the credit rating agencies. The decision that the big three changed their business model from 'investors pay' to 'issuer pay' model led to the dominance of the security issuers over credit rating agencies and consequently it forced credit rating agencies to produce high credit ratings with low informative quality related to credit risk assessments. It is the starting point of conflict of interest in credit rating industry.

The SEC that is responsible for regulating the credit rating industry in the US set up an institution as Nationally Recognized Statistical Rating Organization (NRSRO) that covers the credit rating agencies that are selected eligible for credit rating business in the industry. It is mandatory that only credit rating agencies selected as NRSROs are allowed to produce -in some sense official- credit rating.

The SEC had granted that permission to a handful of credit rating agencies up to the crisis including Moody's, Standard and Poor's and the Fitch out of more than hundred credit rating agencies and this practice of the SEC gave way to a certain kind of oligopoly in credit rating industry dominated by the big three. The fact that the SEC had lengthened the evaluation process of other credit rating agencies applied for NRSRO status and prevented them from taking part in the industry strengthened the oligopolistic status of the big three in the credit rating market (Roubini and Mihm, 2012). Therefore it is the SEC that is responsible for creating oligopoly in credit rating industry.

The factors such as globalization of capital, the SEC's taking as proxy in regulations the credit ratings provided by the agencies with NRSRO status and the very fact that the Basel II framework has referenced to NRSRO credit ratings in determining the capital requirements of the banks worldwide increased the importance of credit ratings and henceforth that of credit rating agencies with NRSRO status that provide those credit ratings.

This dependence of global financial services industry on credit ratings and the oligopolistic status of credit rating agencies in the market had forced them to change their business model in financing the services they provided. Credit rating agencies gave up old 'investors pay business model' in which investors had paid for the credit ratings services and adopted new 'issuers pay business model' in which security issuers had paid for the credit rating services that is obviously more profitable and promises potential business opportunity.

The new 'issuers pay business model' adopted by credit rating agencies that aim at increasing their market share and prospective business opportunities provided by the issuers had paved the way to conflict of interest in credit rating industry. By the new model stemming from the dominance of issuers on credit rating market and the captivity of credit rating agencies to the issuers, credit rating agencies hardly hesitated to provide the securities of the issuers with high credit ratings whose informative quality is extremely poor, and consequently the securities with inflated credit ratings invaded the market.

During the process galloping to the crisis, credit rating agencies kept giving inflated credit ratings to the securities of their customer issuers on the one hand, they gave sudden downgrades to these securities on the other. The turmoil and herd psychology that these sudden downgrades had created in the financial services industry should be taken into consideration in assessing the causes of the crisis.

\section{On the Causes of 2007 Global Financial Crisis}

The causes of 2007 Global Financial Crisis have been profoundly debated in financial and academic circles and examined by the US Congress (Bocutoğlu, 2014, Kuttner, 2013, Roubini and Mihm, 2010, The National 
Commission, 2011). To Soros the crisis is not the result of external shocks but the result of the shocks that are produced by the dynamics within the financial services industry (see Soros, 2014). The Financial Crisis Inquiry Commission that was created by the Congress to examine the causes of the current financial and economic crisis in the United State issued a report. In this report, the Commission presents to the President, the Congress, and the American people the results of its examination and its conclusions as to the causes of the crisis. The majority view of the Commission in the report concluded that "(i) this financial crisis was avoidable, (ii) widespread failures in financial regulation and supervision proved devastating to the stability of the nation's financial markets, (ii) dramatic failures of corporate governance and risk management at many systemically important financial institutions were a key cause of this crisis, (iv) a combination of excessive borrowing, risky investments, and lack of transparency put the financial system on a collision course with crisis, (v) the government was ill prepared for the crisis, and its inconsistent response added to the uncertainty and panic in the financial markets, (vi) there was a systemic breakdown in accountability and ethics, (vii) collapsing mortgagelending standards and the mortgage securitization pipeline lit and spread the flame of contagion and crisis, (viii) over-the-counter derivatives contributed significantly to this crisis and finally (ix) the failures of credit rating agencies were essential cogs in the wheel of financial destruction (The National Commission, 2011).

According to the report, "the three credit rating agencies were key enablers of the financial meltdown. The mortgage-related securities at the heart of the crisis could not have been marketed and sold without their seal of approval. Investors relied on them, often blindly. In some cases, they were obligated to use them, or regulatory capital standards were hinged on them. This crisis could not have happened without the rating agencies. Their ratings helped the market soar and their downgrades through 2007 and 2008 wreaked havoc across markets and firms" (The National Commission, 2011).

\section{Assessments and Conclusions}

During the process tending to crisis, steps are summarized below and the role that CRAs have played can be seen in certain steps:

1. Fed's expansionary monetary policy since 1996 and global financial funds flowing to the USA financial markets such as sovereign state funds increased the money supply and reduced interest rate on the one hand and increased housing prices on the other.

2. Cheap money boosted demand for housing and consequently increasing housing prices gave way to huge housing constructions and created 'malinvestment' in housing sector (see Bocutoğlu and Ekinci, 2010, 2015).

3. Debt claims on mortgage, automobile and student credits were pooled and repacked by the financial institutions and a new financial instrument was born, Collateralized Debt Obligations (CDOs).

4. The CRAs entered the scene at this step during the process. Since the issuers of CDOs needed higher credit ratings for these financial instruments to market them easily, they applied CRAs for higher credit ratings.

5. The oligopolistic structure of credit rating industry and 'issuers pay model' adopted by the CRAs created conflict of interest in the industry. It is the SEC that is responsible for creating oligopoly in credit rating industry.

6. The conflict of interest forced CRAs to produce high credit ratings with low informative quality for CDOs just because CRAs want to make more profit and enjoy the potential business opportunity supplied by their customer issuers.

7. During the process galloping to the crisis, CRAs kept giving inflated credit ratings to the securities of their customer issuers on the one hand they gave sudden downgrades to these securities on the other. The turmoil and herd psychology that the downgrades had created in the financial services industry played a triggering role in 2007 Global Financial Crisis.

8. As the National Commission Report states, the three credit rating agencies were key enablers of the financial meltdown. The mortgage-related securities at the heart of the crisis could not have been marketed and sold without their seal of approval. Investors relied on them, often blindly. In some cases, they were obligated to use them, or regulatory capital standards were hinged on them. This crisis could not have happened without the rating agencies. Their ratings helped the market soar and their downgrades through 2007 and 2008 wreaked havoc across markets and firms.

The key concepts and cases that manifest the role of CRAs in 2007 Global Financial Crisis are (i) increase in importance of CRAs in regulations, determining banks' capital requirements due to Basel II accords and credit ratings of CDOs, (ii) oligopoly in credit rating market created by the SEC, (iii) issuers pay business model, (iv) conflict of interest and dominance of issuers over CRAs, (v) higher credit ratings with lower informative quality about financial assets, (vi) sudden downgrades, (vii) turmoil and herd psychology in financial services industry, and finally (viii) financial meltdown.

The FED, the SEC, issuers and CRAs are responsible as a whole for 2007 Global Financial Crisis. The responsibility of the FED is due to prolonged expansionary monetary policy, that of the SEC is due to oligopoly 
in the credit rating industry, that of the issuers is due to CDOs and conflict of interest and finally that of CRAs is due to conflict of interest and higher credit ratings with lower informative quality about CDOs and sudden downgrades.

As a consequence, D-20 Financial Stability Report (2009) calling governments for reducing dependency on CRAs, National Commission Report (2011) stating that the crisis could not have happened without the rating agencies because their ratings helped the market soar and their downgrades through 2007 and 2008 wreaked havoc across markets and firms, and the fact that the US Security and Exchange Commission (SEC) suspended the activities of Standard and Poor's (S§P) in the Commercial Mortgage Based Securities market for one year during January 21, 2015- January 21, 2016 because of that it caused loses to the investors by slackening secretly the assumptions of its credit rating model it announced publicly and therefore supplying fake - inflated - credit scores are evidence that underlines the responsibility of CRAs in the crisis.

It is obvious that the credit rating industry needs a global reform.

\section{References}

- Benmelech and Dlugosz, 2010. "The Credit Rating Crisis”, National Bureau of Economic Research.

- Bocutoğlu and Ekinci, 2010. "Austrian Business Cycles Theory and Global Crisis", Ludwig von Mises Institute, Daily.

- Bocutoğlu and Ekinci, 2011. "Austrian Business Cycles Theory and Global Financial Crisis: Some Lessons for Macroeconomic Risk and Financial Stability", Ludwig von Mises Institute, Working Paper.

- Bocutoğlu, 2014. ”ABD’de 1933 Glass-Steagall Yasasının Yürürlükten Kaldırılması 2007 Küresel Finansal Krizini Tetikledi mi?: Karşılaştırmalı Bir Değerlendirme”,(Did the Repeal of 1933 Glass-Steagall Act in the USA Trigger the 2007 Global Financial Crisis?: A Comparative Evaluations), Bankacilar Dergisi, Say1:90, pp. 88-100.

- Bocutoğlu and Ekinci, 2015. “A Suggestion: The Malinvestment Index”, George Mason University Working Papers in Economics, No: 15-27.

- Darcy, 2009. "Credit Rating Agencies and the Credit Crisis: How the 'Issuer Pays' Conflict Contributed and What Regulators Might Do About It”, Columbia Business Law Review, 605 (2009).

- Ekins and Calabria, 2012. "Regulation, Market Structure, and Role of Credit Rating Agencies", Policy Analysis, No: 704. August 1, 2012, pp.3-8

- Gudzowski, 2010. "Mortgage Credit Ratings and the Financial Crisis: The Need for a State-Run Mortgage Security Credit Rating Agency”, Columbia Business Law Review, 1 (2010).

- Hunt, (without date), Credit Rating Agencies and the 'Worldwide Credit Crisis': The Limits of Reputation, the Insufficiency of Reforms and a Proposal for Improvement, www2.wiwi.hu-berlin.de/institute /finanz/ scriptsemfin/t12.pdf. pp. 4-13

- Kindleberger and Aliber, 2013. Finansal Krizler Tarihi, Çılgınlık, Panik ve Çöküş, Türkiye İş Bankası Genel Yayın No: 2819, İstanbul.

- Kuttner, 2013. "Seven Deadly Sins of Deregulation and Three Necessary Reforms", The American Prospect, prospect.org/article/seven-deadly-sins-deregulation-and-three-necessary-reforms, pp. 1-4.

- McVea, 2010. "Credit Rating Agencies, Subprime Mortgage Debacle and Global Governance: The EU Strikes Back”, International and Comparative Law Quarterly, 59, pp.702-708.

- Mian and Sufi, 2009. "The Consequences of Mortgage Credit Expansions: Evidence from the US Mortgage Default Crisis", The Quarterly Journal of Economics, 2009, 124 (4).

- The National Commission, 2011. The Financial Crisis Inquiry Report, Official Government Edition, FCIC Website, pp. xvii-417-719.

- Partney, 1999. "The Siskel and Ebert of Financial Markets?: Two Thumbs Down For the Credit Rating Agencies", Washington University Law Quarterly, Vol:77, No: 3 (1999).

- Roubini and Mihm, S., (2012), Kriz Ekonomisi, Finansın Geleceğine Dair Hızlandırılmış Bir Kurs, (Crisis Economics: A Crash Course in the Future of Finance), Pegasus Yayınları: 442, Ekonomi:3, İstanbul, pp.69207.

- Ryan, J., (2012), “The Negative Impact of Credit Rating Agencies and Proposals for Better Regulation”, Working Paper, FG 1, No: 01, Research Division EU Integration, German Institute for International and Security Affairs, SWP Berlin, pp. 6-12.

- Soros, G., (2014), “Anatomy of a Crisis”, www.georgesoros.com/interview. 22.08.2014.

- Whitehouse, K., (2015), “SEC Charges Ratings Agency S§P over Ratings”, USA Today, 21 January 2015 